the good fortune that always accompanies the strong and the brave. Both Peary and Amundsen did more than discover the Poles. They besieged them, and the mysteries at last were unveiled to those who had the will and patience, the skill and the perseverance to dominate the situation.

For many years Captain Amundsen has been considered one of the most daring and skillful of Polar explorers. He has been a sailor from his youth. At the age of twenty-five he sailed with the "Belgica" expedition to the Antarctic. On his return he decided to devote the rest of his life, if need be, to the endeavor to discover the famous Northwest Passage which had been sought for more than three centuries by such daring sea spirits as Frobisher, Cabot, and Franklin. For two years Amundsen studied magnetism and meteorology. Then in June, 1903, in the "Gjoa," he set sail from Christiania. After three years' wanderings through the ice, rocks, and unknown lands of the Northwest, he eventually brought his little vessel through Behring Strait, and thus for the first time navigated the Northwest Passage. During this voyage he determined exactly the position of the magnetic pole.

Amundsen is forty years old, a strong-willed character of scientific equipment and modest as to his own achievements. He speaks highly of the work of the Japanese expedition, with which he came into contact on the trip, and refers respectfully and sympathetically to the expedition of Captain Robert Scott, the English explorer who left New Zealand on the other side of the globe from Captain Amundsen at about the same time. The equipment of Captain Scott's party and his own qualifications, aided as they have been by the advice and experience of Sir Ernest Shackleton, uere believed to have given him even a better start in the search for the Pole than his Norwegian rival. Very soon after the start of these two men, the world began to refer to their efforts as a race. Scott's party intended to be more deliberate in its work, making scientific investigations and explorations of a more extended sort than Amundsen had set himself to do. It was expected that Scott would attain the Pole at about the time Amundsen actually reached it. The Norwegian, however, saw nothing of his English rival, and the latter had not been heard from up to the middle of last month. Amundsen admitted that Scott might have been at the Pole before his own party, and might have left a memorial that had possibly been swept away by storms. His own base, he said, was 500 miles from that of the British party. "I sincerely hope," he told the newspaper reporters, "that Scott's expedition was successful."-American Review of Reviezes.

\title{
ASSOCIATION OF MATHEMATICS TEACHERS IN NEW FNGLAND.
}

The midwinter meeting of this association was held at Wilson Hall, Brown University, Providence, R. I., on February 2, 1912, at 2 P. M.

Professor R. C. Archibald of Brown University delivered an address on "Mathematical Instruction and the Professors of Mathematics in the French Lycées," and Mr. A. H. Morrison of the Mechanic Arts High School, Boston, spoke on "Mathematics in Elementary Schools."

The two papers were discussed for a half hour by the members present.

H. D. GAYLORD, Secretary. 